\title{
The morphotaxonomy and distribution of the genus Palisada Nam (Ceramiales, Rhodophyta) from Myanmar
}

\begin{abstract}
The three species of the genus Palisada Nam collected from the coastal areas between Zar Det Gyi I. (Lat. $09^{\circ} 56^{\prime} \mathrm{N}$, Long. $98^{\circ} 11^{\prime} \mathrm{E}$ ) of the Taninthayi Coastal Zone and Kyauk Phyu (Lat. $19^{\circ} 26^{\prime} \mathrm{N}$, Long. $93^{\circ} 33^{\prime} \mathrm{E}$ ) of the Rakhine Coastal Zone, had been identified as $P$. parvipapillata (CK Tseng) KW Nam, P. intermedia (Yamada) KW Nam and P. perforata (Bory) KW Nam, based on the external and internal morphologies of the vegetative and reproductive structures. The comparison of the characteristics and key to the species of Palisada Nam from Myanmar were provided. All these 3 species of the genus Palisada Nam were newly recorded from Myanmar waters. With regard to local distribution, the plants of P. intermedia (Yamada) KW Nam occur only in the Rakhine Coastal Zone, whereas those of P. perforata (Bory) KW Nam and P. parvipapillata (CK Tseng) K.W. Nam predominate in both the Tanintharyi and Rakhine Coastal Zones. The vertical phytogeographical distribution is wide for P. parvipapillata (CK Tseng) KW Nam and P. perforata (Bory) $\mathrm{KW}$ Nam, but narrow for $P$. intermedia (Yamada) KW Nam in all tropical and temperate oceans. In horizontal phytogeographical distribution, P. perforata (Bory) KW Nam and $P$. intermedia (Yamada) KW Nam extensively dominate in the Atlantic, Indian and Pacific Oceans, while $P$. parvipapillata (CK Tseng) KW Nam predominantly occurs in the Indian and Pacific Oceans.
\end{abstract}

Keywords: ceramiales, distribution, morphology, Myanmar, Palisada Nam, Rhodophyta, taxonomy
Volume 7 Issue 3 - 2018

\author{
Soe Pa Pa Kyaw,' U Soe-Htun² \\ 'Department of Marine Science, Mawlamyine University, \\ Myanmar \\ ${ }^{2}$ Director, Marine Science Association, Myanmar, (MSAM), \\ Yangon, Myanmar
}

Correspondence: Soe Pa Pa Kyaw, Department of Marine Science, Mawlamyine University, Myanmar, Email soepapakyaw.marine@gmail.com

Received: March 23, 2018| Published: June 20, 2018

\section{Introduction}

Saito $^{1}$ established the Laurencia complex into five sectionsLaurencia, Forsterianae, Pinnatifidae, Chondrophycus and Palisadae, based on the characteristics by the presence or absence of a palisadelike arrangement of epidermal cells, presence or absence of lenticular thickenings in the walls of medullary cells, thalli clearly compressed, presence or absence of secondary pit connections between epidermal cells and parallel or right-angle arrangement of tetrasporangia.

The Laurencia complex was recently divided into four genera: Laurencia Lamouroux (1813), Chondrophycus (Tokida et Saito) Garbary and Harper (1998), Osmundea Stackhouse (1809) and Palisada Nam (2007), based on vegetative and reproductive structures. ${ }^{1-3}$ The genus Laurencia is distinguished from the other three genera in having four pericentral cells per axial segment (two pericentral cells in Osmundea, Condrophychus and Palisada). The genus Osmundea is distinguished from the other genera in having tetrasporangial production from random epidermal cells rather than from particular pericentral cells and filament-type rather than trichoblast-type spermatangial development. The genus Chondrophycus differs from others in having the first pericentral cell with lateral position of the trichoblast; spermatangial branches produced from two laterals on the suprabasal cell of a trichoblast but remaining partly sterile; tetrasporangial axis with both the first and the second pericentral cells sterile. ${ }^{4} \mathrm{Nam}^{3}$ established the genus Palisada characterized by the absence of secondary pit-connections between the superficial cortical cells and lenticular thickenings of the medullary cell walls, as well as by the tetrasporangial arrangement with the right angle type in the apical portion of the fertile ultimate branchlets. Tetraspores are tetrahedrally divided in all species of the genus Palisada. Currently, 20 species of Palisada were recorded, widely occurring along temperate and tropical seas. ${ }^{5}$

In Myanmar, Kyi Win ${ }^{6}$ and Kyaw Soe and Kyi Win ${ }^{7}$ reported Palisada perforata (Bory) KW Nam as Laurencia papillosa (Forsk) Greville, Soe-Htun et al., ${ }^{8,9}$ also recorded Palisada perforata (Bory) KW Nam as Chondrophycus papillosa (C Agardh) Garbary and Harper, and P. intermedia (Yamada) Nam as Chondrophycus intermedius (Yamada) Garbary and Harper. Zayar Aung ${ }^{10} \&$ Myo Min Tun ${ }^{11}$ identified only one species of Palisada as P. parvipapillata (CK Tseng) KW Nam from Kampani coastal areas. Moreover, Soe Pa Pa Kyaw $^{12}$ also identified three species of Palisada, viz., P. parvipapillata (C.K. Tseng) KW Nam, P. intermedia (Yamada) KW Nam and $P$. perforate (Bory) K.W. Nam from three Coastal Zones of Myanmar.

The objectives of this study are: 1) to identify the species of Palisada using the detailed morphological characteristics of vegetative and reproductive structures, and 2) to know the distribution ranges of the species of Palisada growing along both the three Coastal Zones of Myanmar and the coastal areas of the world.

\section{Materials and Methods}

The fresh (wet-stack) specimens preserved in $4 \%$ formaldehyde and seawater and dried herbarium specimens of the plants of the genus Palisada collected from the three Coastal Zones, Taninthayi Coastal Zone, Deltaic Coastal Zone and Rakhine Coastal Zone of Myanmar (Figure 52), and deposited in the Herbarium of Department of Marine Science, Mawlamyine University, Myanmar (MMB), from 1971 to 2013, were used for the identification of the species of Palisada, emphasized on morphology of the external and internal vegetative and reproductive structures. 
The fragments of plant were squashed on microscope slides, and stained with aniline blue $(0.5 \mathrm{~g}$ water soluble aniline blue in $100 \mathrm{ml}$ distilled water and $5 \mathrm{ml}$ conc. Acetic acid) and acid fuchsin ( $1 \%$ solution in distilled water and $70 \%$ alcohol) for detailed observations. The sections were prepared by hand using razor blades. Microscopic measurements were recorded in micrometer $(\mu \mathrm{m})$ using the ocular meter. External and internal morphological structures were photographed with a Panasonic (Lumix) DMC-TZ 15 digital camera and processed using Adobe Photoshop CS.

Local distribution of the genus Palisada was arranged from the herbarium specimens examined. Phytogeographical distribution and potential uses of each species were prepared with the data from the literature collected. Ecological notes and associated algae of this species were also recorded during the periods of collections of specimens in the field.

This study follows the classification systems used by Saito, Nam, Guiry et al., ${ }^{1,3,5,13}$ \& Cordero, Silva et al. ${ }^{14,15}$

\section{Results}

The marine benthic red algal species of the genus Palisada Nam (Ceramiales, Rhodophyta) collected from the 3 Coastal Zones of Myanmar from 1971 to 2013, were identified as P. parvipapillata (CK Tseng) KW Nam, $P$. intermedia (Yamada) $\mathrm{KW}$ Nam and $P$. perforata (Bory) KW Nam, mainly based on the external and internal morphologies of the vegetative and reproductive structures.

\section{A classification of the genus Palisada}

Phylum: Rhodophyta

Class: Florideophyceae

Order: Ceramiales

Family: Rhodomelaceae

Genus: Palisada Nam

Section: Palisadae Yamada

Species: P. parvipapillata (CK Tseng) KW Nam, P. intermedia (Yamada) KW Nam, P. perforata (Bory) KW Nam

Palisada parvipapillata (CK Tseng) KW Nam (Figures 1-19)

Type locality: Cape de'Aguilar, Hong Kong ${ }^{16}$

Description: Vegetative Structures

External features: Fronds (Figure 1) (Figure 2), prostrate (or decumbent), about $2.5 \mathrm{~cm}$ high, grow on rock, and attach to the substratum by stoloniferous discoid holdfast (Figure 6) in the lower intertidal zone; rigid in texture, and cartilaginous; brownish red (or) purplish colour; main axes percurrent, $1175-2050 \mu \mathrm{m}$ long, and $725-1125 \mu \mathrm{m}$ broad; secondary branches (Figure 3) (Figure 4), 950$1575 \mu \mathrm{m}$ long, and $650-1025 \mu \mathrm{m}$; branching pinnately (or) alternately; corps en cerise absence. In a surface view, the cortical cells in the main axis, rounded polygonal, 20-32 $\mu \mathrm{m}$ broad (Figure 7); while those in the secondary branch, elongated or more or less rounded, $12-24 \mu \mathrm{m}$ broad. Lateral secondary pit connections between cortical cells are present. Sometimes, the secondary pit connections between cortical cells are fused (Figure 8).

Internal features: In transverse section, main axes (Figure 9), 850$1000 \mu \mathrm{m}$ in diameter; cortical cells, elongated, and palisade-like layer;
$20-48 \mu \mathrm{m}$ long, and $12-20 \mu \mathrm{m}$ broad in the lower to upper portions; with secondary pit connections (Figure 11) between these cells. The outer surface of the cortical cell wall projected to the surface (Figure 10). Medullar cells, more or less rounded or elongated; 44-140 $\mu \mathrm{m}$ long, and $28-88 \mu \mathrm{m}$ broad in the lower to upper portions; with intercellular spaces (Figure 14) between these cells, lenticular thickenings in the walls of the medullary cells absent; two pericentral cells peraxial cells (Figure 15). The primary and secondary pit connections between medullary cells are present. In longitudinal section, main axes (Figure 12), $700-800 \mu \mathrm{m}$ broad; cortical cells, elongated, and palisadelike layer; $28-40 \mu \mathrm{m}$ long, and 12-24 $\mu \mathrm{m}$ broad, with secondary pit connections (Figure 13) between these cells; medullary cells, elongated, $120-290 \mu \mathrm{m}$ long, and $60-100 \mu \mathrm{m}$ broad. The apical pit sunk in the apical depression (Figure 5). The vegetative trichoblasts (Figure 17), $104 \mu \mathrm{m}$ long, are repeatedly dichotomously branched.

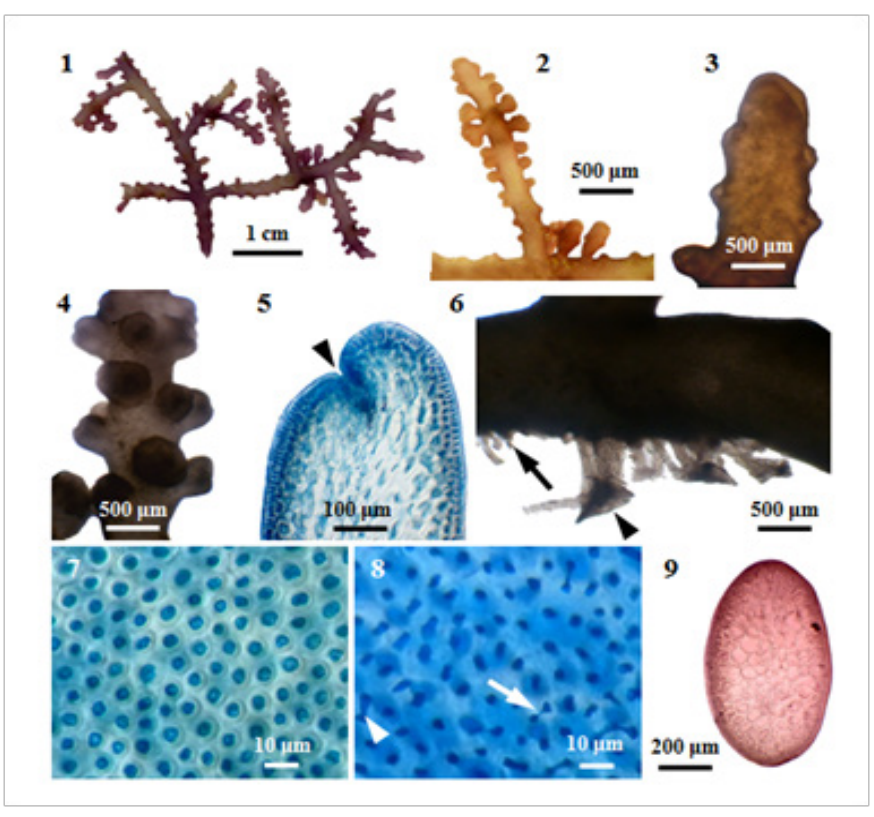

Figures I-9 Morphology and anatomy of P. parvipapillata (CK Tseng) KW Nam. (I) Habit of a plant. (2) Upper part of secondary branches. (3) Apical portion of main axis with secondary branches. (4) Middle portion of main axis. (5) Longitudinal section of apex of a branch, showing apical depression (arrowhead); (6) Discoidal holdfast (arrowhead) and the stolon-like branch (arrow). (7) Surface view of main axis, showing polygonal or rounded cortical cells. (8) Surface view of secondary branch, showing the fusion of cortical cells (arrowhead) through secondary pit connections (arrow). (9) Cross section of main axis, showing compressed frond.

Reproductive Structures: The spermatangial stichidia (Figure 18), formed on the apical portions of main axis; simple, $1025-1525 \mu \mathrm{m}$ long, and $1125-1850 \mu \mathrm{m}$ broad; with apical cup-shaped spermatangial pits, $1125-1850 \mu \mathrm{m}$ broad and contain numerous fertile trichoblasts. Trichoblasts (Figure 19), consist of a repeatedly dichotomously branched; terminate in a single sterile cell, $8-12 \mu \mathrm{m}$ in diameter.

Specimens examined: Taninthayi Coastal Zone: Hmyawyit (Zayar Aung, 16.iii.2011; MMB 11589; sterile; Myo Min Tun, 27.ix.2012; MMB 11778; sterile), Kanpani (Zayar Aung, 15.iii.2011; MMB 11588; sterile); Deltaic Coastal Zone: No Data; Rakhine Coastal Zone: Ngwe Saung (Minn-Lann) (San Tha Tun and Mya Kyawt Wai, 14.xi.2009; MMB 11678; sterile, ठ̂).

Distribution: (i) Myanmar distribution- Taninthayi Coastal Zone: 
Hmyawyit, Kampani; Deltaic Coastal Zone: No data; Rakhine Coastal Zone: Ngwe Saung (Minn-Lann)(Figure 52). (ii) World-wide.

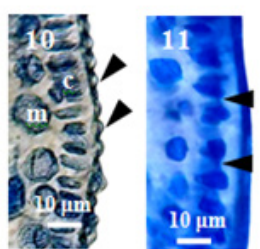

12
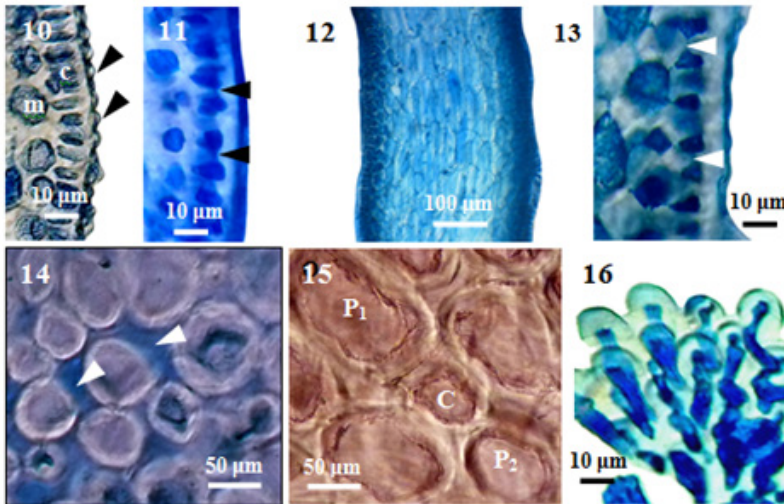

16

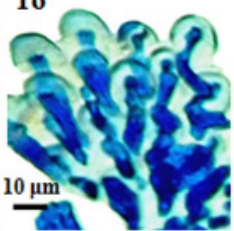

17

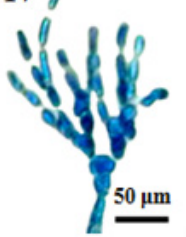

18

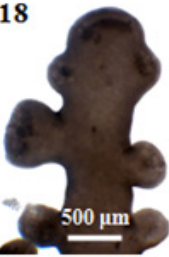

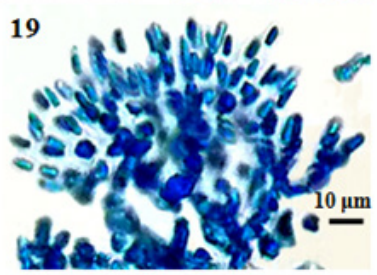

Figures I 0-I 9 Morphology and anatomy of P. parvipapillata (C.K.Tseng) K.W. Nam. (10) Cross section of main axis, showing the projections of cortical cells (arrowheads), medulla (m) and palisade-like cortical cells (c). (I I) Cross section of main axis, showing secondary pit-connection (arrowheads) and fusion between contiguous superficial cortical cells. (12) Longitudinal section of main branch. (13) Longitudinal section of main axis, showing secondary pit-connection (arrowheads) between contiguous superficial cortical cells. (14) Cross section of main axis, showing intercellular spaces (arrowheads) between medullary cells. (I5) Cross section of main axis, showing central (c) and two pericentral (p) cells. (16) Projection of cortical cells in a branch. (17) Trichoblast of sterile plant. (18) Part of a spermatangial (male) plant. (19) Trichoblast of male plant.

Distribution Pacific Ocean: China (Hong Kong), Japan, Philippines, Micronesia, Australia, New Zealand, Hawaiian I., Fiji I.; Indian Ocean- Africa, Kenya, Somalia, Maldives, Yemen; Seychelles, Myanmar (Present study); Indo-Pacific Region- Malaysia, Indonesia. ${ }^{5}$ (Figure 53).

Ecological notes: This plants grow on rocks in the lower intertidal zone, and attached to the substratum by discoid holdfast with stolon-like branches. The vegetative or reproductive plants can be found from September to November, till March. Associated algal species are- Lyngbya sp., Ulva intestinalis, Chaetomorpha gracilis, Ceramium sp., Roschera glomerulata, Centroceras clavulatum, Hypnea spinella, Gracilaria crassa, G. foliifera, Laurencia papillosa, Gelidium arenarium, Polysiphonia subtilissima. Potential uses: The utilization of this species is unknown. Palisada intermedia (Yamada) K.W. Nam (Figures 20-33) Type locality: Enoshima, Kanagawa Prefecture, Japan. ${ }^{16}$

Description: Vegetative Structures: (i) External features: Fronds, erect (Figure 20), with several erect axes loosely tufted, up to $5 \mathrm{~cm}$ high, purplish, rigid, cartilaginous in texture, attached to the substratum by discoid holdfast, and sometimes slightly entangled with coalesced stoloniferous branches, never adhere to paper when drying; main axes, terete with blunt tips terminate in a small depression (Figure 22), 1125-1250 $\mu \mathrm{m}$ in diameter; branches (Figure
21) cylindrical, opposite or subverticillate, $800-1050 \mu \mathrm{m}$ long and at angles of $10-90^{\circ}$. In a surface view, the cortical cells in the main axis (Figure 23), hexagonal, $8-18 \mu \mathrm{m}$ long and $8-13 \mu \mathrm{m}$ broad, while those in the secondary branch (Figure 24), longitudinally elongated, 10$70 \mu \mathrm{m}$ long and $10-18 \mu \mathrm{m}$ broad.
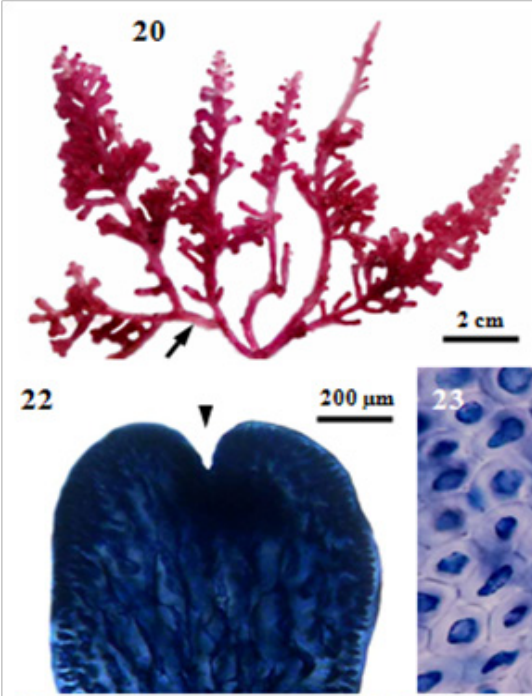

21
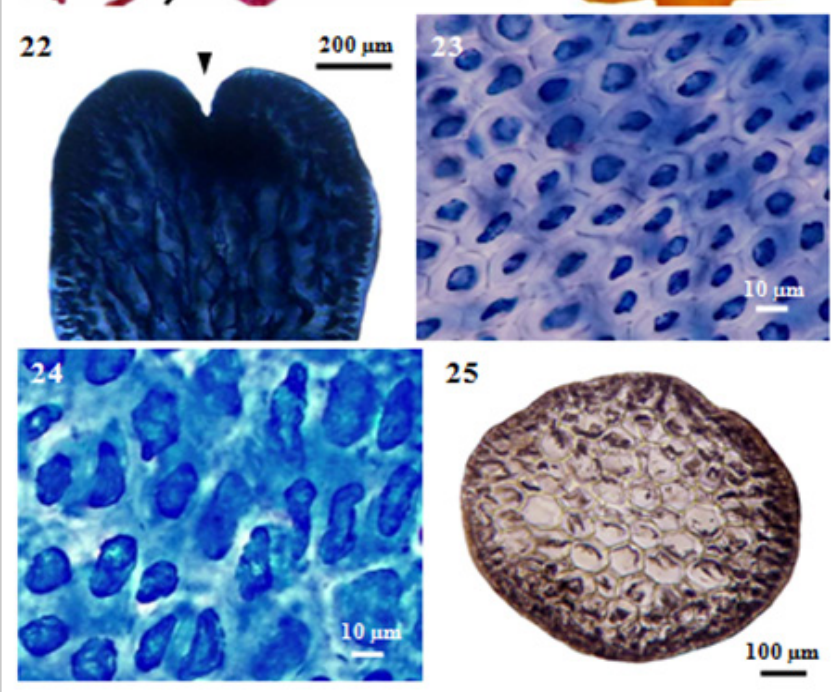

Figures 20-25 Morphology and anatomy of $P$. intermedia (Yamada) KW Nam. (20) Habit of a plant, showing stoloniferous branches (arrow). (2I) Part of a sterile plant. (22) Apex of a branch showing apical depression (arrowhead). (23) Surface view of main branch, showing hexagonal shaped cortical cells. (24) Surface view of secondary branch, showing longitudinally elongated cortical cells. (25) Cross section of main branch.

Internal features: In transverse section, main axes (Figure 25), $800-1150 \mu \mathrm{m}$ diameter in the lower portions, $720-920 \mu \mathrm{m}$ in the middle portions, and then gradually taper to $590-660 \mu \mathrm{m}$ at the tips; cortical cells (Figure 26), not protrude at the apex, form a palisadelike layer, $20-33 \mu \mathrm{m}$ long and $10-18 \mu \mathrm{m}$ broad in the lower to upper portions, without secondary pit connections between these cells; medullary cells (Figure 27), rounded or more or less elongated, 50$190 \mu \mathrm{m}$ diameter in the lower to upper portions, with primary and secondary pit connections (Figure 28), without intercellular spaces between these cells (Figure 27), lenticular thickenings in the walls of the medullary cells absent; two pericentral cells per axial cell (Figure 29); secondary branches, $750-850 \mu \mathrm{m}$ in diameter; cortical cells, not protrude at the apex, form a palisade-like layer, $25-43 \mu \mathrm{m}$ long and 13$25 \mu \mathrm{m}$ broad; medullary cells, rounded or more or less elongated, $50-$ $120 \mu \mathrm{m}$ in diameter; two pericentral cells per axial cell. In longitudinal section, main axes (Figure 30), 1125-1250 $\mu \mathrm{m}$ broad; cortical cells (Figure 31), elongated and arranged like palisade cells, $10-48 \mu \mathrm{m}$ long and $15-28 \mu \mathrm{m}$ broad; medullary cells, elongated, $190-330 \mu \mathrm{m}$ long and $70-150 \mu \mathrm{m}$ broad. 
Reproductive Structures: Tetrasporangial stichidia (Figures 32-33), formed on the secondary branches; simple or in clusters, cylindrical to clavate, $625-1650 \mu \mathrm{m}$ long and $550-900 \mu \mathrm{m}$ broad. Tetrasporangia, originate from a pericentral cell near the growing apex in the apical depression of a branchlet; spherical, tetrahedrally divided; and 90$100 \mu \mathrm{m}$ in diameter; arranged at right angles to the central axis (Figure $33)$. In the present study, spermatangial and cystocarpic plants are unknown.
26
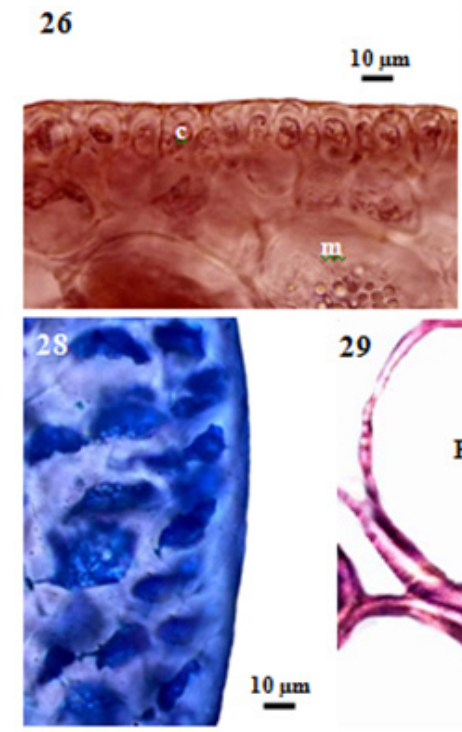
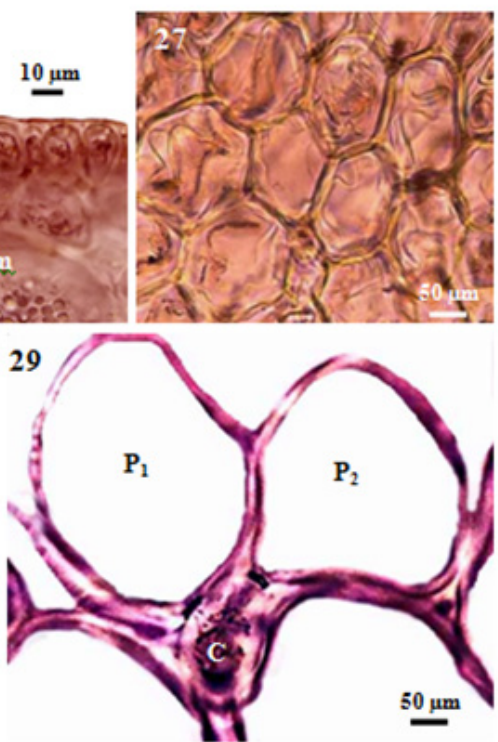

Figures 26-29 Morphology and anatomy of $P$. intermedia (Yamada) KW Nam. (26) Cross section of main axis, showing medulla $(\mathrm{m})$ and palisade-like cortex (c) cells. (27) Cross section of main axis showing the absence of intercellular spaces between medullary cells. (28) Cross section of main axis, showing the absence of secondary pit connections between cortical cells. (29) Cross section of main axis, showing central (c) and two pericentral (p) cells.

Specimens examined: Taninthayi Coastal Zone: No data; Deltaic Coastal Zone: No data; Rakhine Coastal Zone: Shwe Ya Gyaing (SoeHtun, 5.x.2002; MMB 07326: sterile, ).

Distribution: (i) Myanmar distribution- Taninthayi Coastal Zone: No data; Deltaic Coastal Zone: No data; Rakhine Coastal Zone: Shwe Ya Gyaing ${ }^{8,9}$ (Figure 52). (ii) World-wide distribution- Pacific OceanSouth America: Venezuela, Fiji Is; Atlantic Ocean- Atlantic Islands: Cape Verde Is., Africa: Liberia, Ghana, Turkey (Europe-Asia); Indian Ocean- Kenya, Tanzania, Red Sea, Indian Ocean Islands: Reunion, South-west Asia: Sri Lanka (Ceylon), Myanmar (Present study); Indo-Pacific Region- Asia: China, Taiwan, Japan, South-east Asia: Philippines, Korea. ${ }^{5}$ (Figure 53).

Ecological notes: Plants grow on rocks in the lower intertidal to subtidal zones. This species attached to the substratum by means of discoidal holdfast, and sometimes slightly entangled with coalesced stoloniferous branches. The vegetative or reproductive plants can be found in October. Associated algal species are Laurencia sp. and Acanthophora spicifera.

Potential uses: Laurinterol, laurenisol and isolaurentinol compounds which were of medicinal values, were isolated from the methanolic extracts from P. intermedia (Yamada) K.W. Nam ${ }^{17}$, Dembitsky and Tolstikov. ${ }^{18}$
30

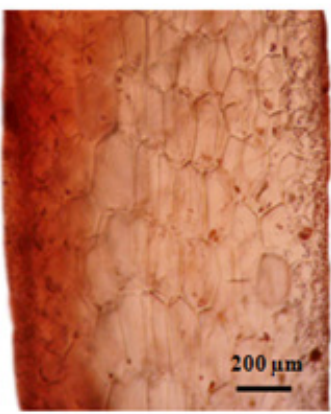

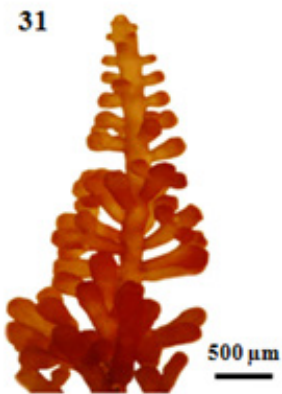

32

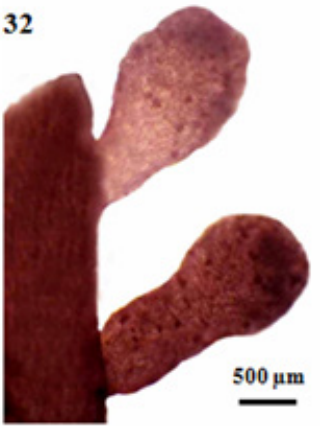

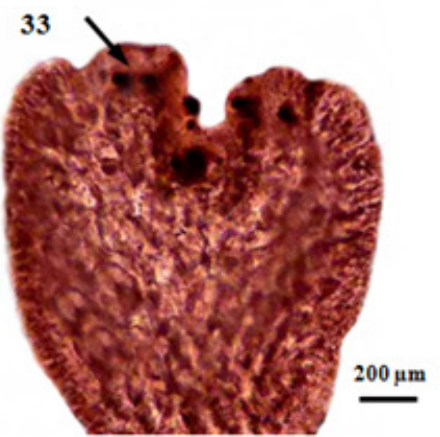

Figures 30-33 Morphology and anatomy of $P$. intermedia (Yamada) Nam. (30) Longitudinal section of main branch. (3I) Part of a tetrasporangial plant. (32) Tetrasporangial stichidia (arrow) on main axis. (33) Longitudinal section of tetrasporangial stichidium, showing right angle arrangement of tetrasporangia (arrow).

\section{Palisada perforata (Bory) K.W. Nam (Figures 34-5I)}

Type locality: "rade de Sainte-Croix" (Santz Cruz de Tenerife), Islas Canarias. ${ }^{16}$

Description: Vegetative Structures: (i) External features: Fronds (Figure 34), erect or prostrate, 1.0-3.5 cm high, attached on rocks, grow together with Gracilaria crassa in lower intertidal or subtidal zone, erect branches (Figure 35) arise from the stolon-like branch; rigid in texture, and cartilaginous; yellowish (or) greenish to purplish when fresh; main axes arise from discoid holdfast (Figure 34), 850$1000 \mu \mathrm{m}$ in diameter; 2-11 number of upright axes from the base of branches; secondary branches (Figure 35-36), 500-1150 $\mu \mathrm{m}$ long, and 250-1050 $\mu \mathrm{m}$ broad; branching di-tristichous, whorl or alternately dichotomous or irregularly spirally arranged; corps en cerise absence. In a surface view, the cortical cells in the main axis (Figure 38), more or less rounded, $8-20 \mu \mathrm{m}$ in diameter; while those in the secondary branch (Figure 39), elongated or more or less rounded, $12-20 \mu \mathrm{m}$ long, and $12-16 \mu \mathrm{m}$, rounded, $12-20 \mu \mathrm{m}$ long, and $12-16 \mu \mathrm{m}$ broad in the lower to upper portions, with secondary pit connections (Figure 42) between these cells; medullary cells, more or less rounded, 52$100 \mu \mathrm{m}$ diameter in the lower to upper portions, with intercellular spaces (Figure 43) between these cells, lenticular thickenings in the walls of the medullary cells absent; two pericentral cells peraxial cells (Figure 44). In longitudinal section, main axes (Figure 45), 800$1000 \mu \mathrm{m}$ broad; cortical cells, radially elongated, 16-24 $\mu \mathrm{m}$ long, and 
$8-12 \mu \mathrm{m}$ broad; medullary cells, more or less rounded (or) elongated, $80-210 \mu \mathrm{m}$ long, and 50-100 $\mu \mathrm{m}$ broad.

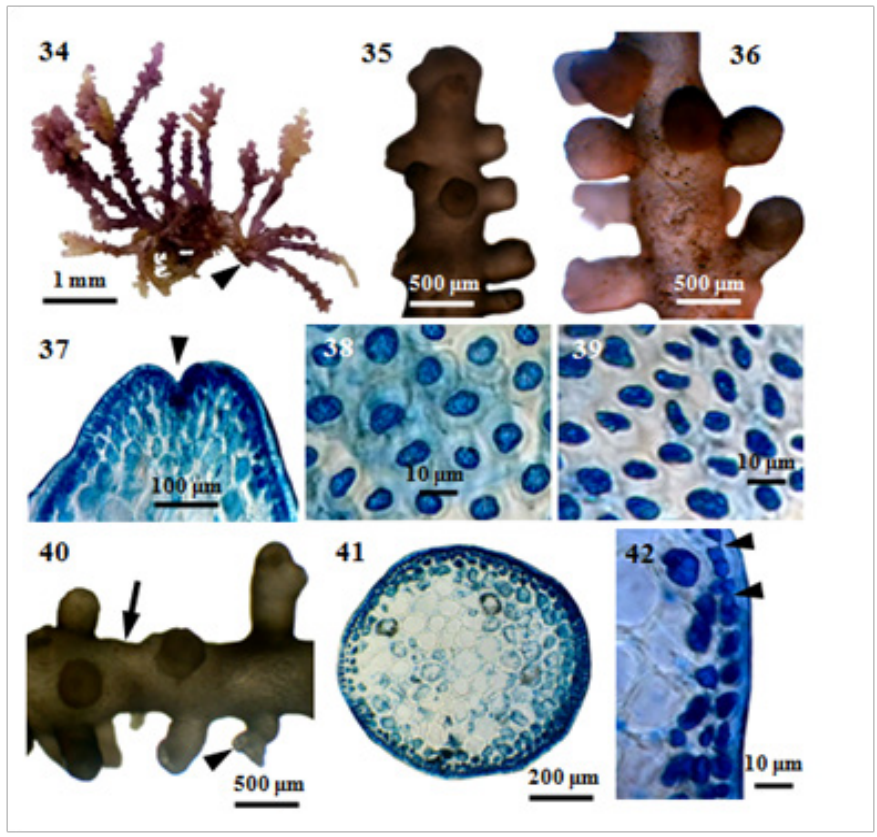

Figures 34-42 Morphology and anatomy of P. perforata (Bory) KW Nam. (34) Habit of a plant. (35) Apical portion of a plant with secondary branches. (36) Middle portion of a plant with secondary branches. (37) Apex of a branch, showing apical depression (arrowhead). (38)Surface view of main axis, showing more or less rounded cortical cells. (39) Surface view of secondary branch, showing more or less rounded or elongated cortical cells; (40) Secondary discoid holdfast (arrowhead) with stolon-like branch (arrow). (4I) Cross section of main axis. (42) Cross section of main axis, showing secondary pit connections (arrowheads) between cortical cells.

\section{Reproductive Structures}

In the carposporic plant (Figure 49-51), cystocarps, formed on the secondary branches; single, occasionally two, ovoid, with wide apical ostiole, $625-1375 \mu \mathrm{m}$ long, and 550-875 $\mu \mathrm{m}$ broad. Plants, dioecious; the spermatangial stichidia (Figure 47), formed on the apical portions of main axis; simple, turbinate, 325-1250 $\mu \mathrm{m}$ long, and 625-1625 $\mu \mathrm{m}$ broad; with apical cup-shaped spermatangial pits, $375-1000 \mu \mathrm{m}$ broad and contain numerous fertile trichoblasts. Trichoblasts (Figure 48), consist of a repeatedly dichotomously branched; terminate in a single large sterile vesicular cell, $40-48 \mu \mathrm{m}$ in diameter. The tetrasporangial plants have not been found.

\section{Specimens examined:Taninthayi Coastal Zone}

Zar Det Gyi I. (Yin Yin Htay, 2.iv.2013; MMB 111175, 111177 sterile; San Tha Tun, 3.iv.2013; MMB 111176: sterile); Deltaic Coastal Zone: No data; Rakhine Coastal Zone: Kyauk Phyu (San Tha Tun, 25.ii.1987; MMB 07522: sterile); Mazin (San Tha Tun, 17.iii.1987; MMB 07521: sterile); Pho Htaung Gyaing (Soe-Htun, 3.iv.1996; MMB 03283: sterile); Ta-Jet Is. (Han Shein, 31.xii.1971; MMB 01041: sterile); Ngwe Saung (Soe Pa PaKyaw, 26.iv.2012; MMB 11683-11688: sterile; Soe Pa Pa Kyaw and May Mon, 26.iv.2012; MMB 11689: sterile; Mya Kyawt Wai, 22.iv.2013; MMB 111173: o; MMB 111174: sterile); Zea Gyaing (Ma Thida, 8.iii.1984; MMB 02964: sterile); Kyar Kan (Mya Kyawt Wai et al.,14.xi.2009; MMB 11677: sterile); Mawtin Point (Ma Myint Than and Mu Mu
Aye, 18.ii.1980; MMB 00995, 07519: sterile; Mya Kyawt Wai et al., 17.xi.2009; MMB 11676: sterile, ふૈ).
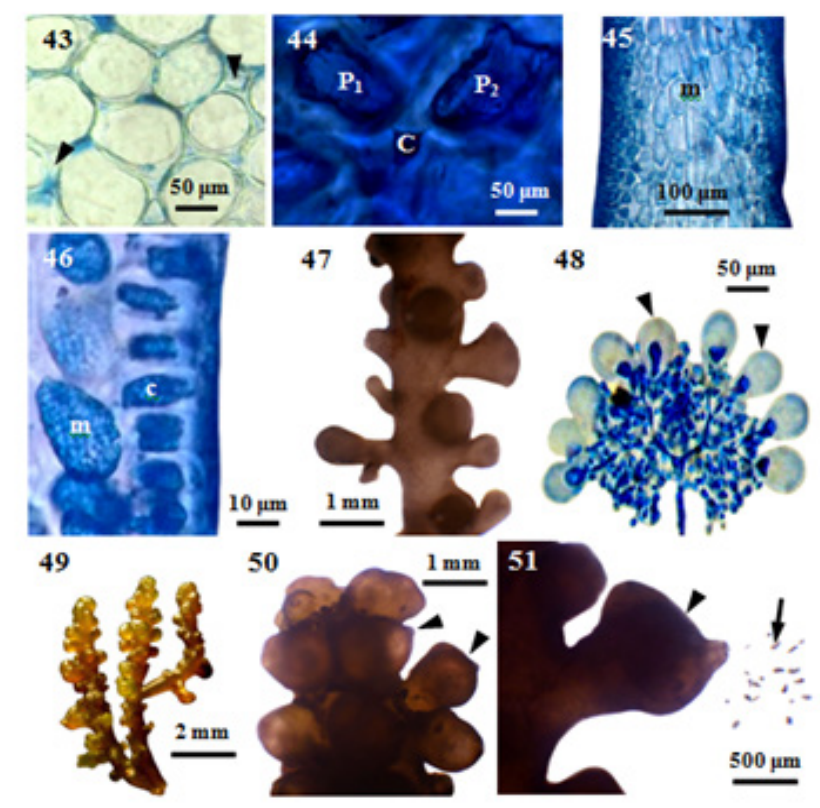

Figures 43-5 I Morphology and anatomy of P. perforata (Bory) KW.Nam. (43) Cross section of main axis, showing intercellular spaces (arrowheads) between medullary cells. (44) Cross section of main axis showing central (c) and two pericentral $(p)$ cells. (45) Longitudinal section of main axis, showing elongated medullary cell $(\mathrm{m})$. (46) Longitudinal section of main axis showing medulla $(\mathrm{m})$ and radially elongated cortex (c) cells. (47) Part of a spermatangial plant. (48) A cluster of mature spermatangia, showing sterile vesicular cell (arrowheads). (49) Part of a young carposporic plant. (50) Apical portion of carposporic plant, showing cystocarps (arrowheads). (5I) A mature cystocarp (arrowhead) and released carpospores (arrow) from the ostiole.

\section{Distribution}

Myanmar distribution-Taninthayi Coastal Zone: Zar Det Gyi I.; Deltaic Coastal Zone: No data; Rakhine Coastal Zone: Kyauk Phyu, Mazin, Pho Htaung Gyaing, Ta-Jet Is., Ngwe Saung, Ngwe Saung (Kyar Kan), Zea Gyaing, Mawtin Point (Figure 52). (ii) Worldwide distribution- Pacific Ocean- Fiji, Mexico, Florida, Costa Rica, Trinidad, Cuba, Bahamas, Bermuda, Panama, Caicos Is., Puerto Rico, Colombia, Brazil, Venezuela, France, Martinique, Lesser Antilles, Tanzania, Australia, New Zealand, Hawaiian I.; Atlantic OceanCanary I., Spain, Nertherland, Tunisia, Adriatic, Malta, Greece, Bulgaria, Turkey, Mediterranean Sea, Egypt, Israel, Jordan, Gabon, Queensland,; Indian Ocean- Sudan, Somalia, Saudi Arabia, Ethiopia, Yemen, Kenya, Mozambique, Seychelles, Oman, Bahrain, India, Sri Lanka, Myanmar (Present study), Andaman I., Nicobar I., Mauritius; Indo-Pacific Region- Indonesia, Vietnam, China (Hong Kong), Taiwan, Korea, Japan, Philippines, Thailand, Malaysia ${ }^{5}$ (Figure 53).

Ecological notes: This plants grow on rocks in the lower intertidal or subtidal zone and attached to the substratum by discoid holdfast with stolon-like branches. The vegetative or reproductive plants can be found from November to December, and February to April. Associated algae of $P$. perforata (Bory) KW Nam are Lyngbya sp., Schizothrix sp., Ulva intestinalis, Cladophora vagabunda, Cladophoropsis elegans, Gelidium arenarium, Hypnea pannosa, Gracilaria foliifera, 
Centroceras clavulatum, Ceramium sp., Polysiphonia substilissima and Acanthophora spicifera.

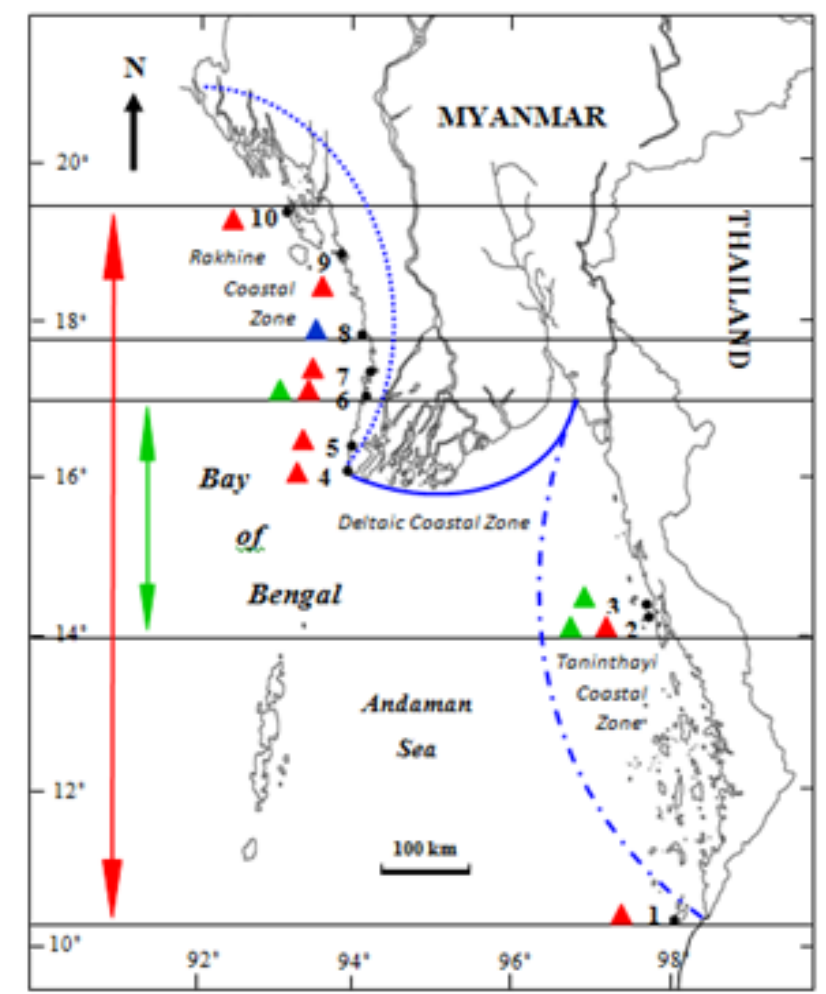

Figure 52 Local distribution of the genus Palisada Nam in Myanmar. I. Zar Det Gyi I. 2. Kampani. 3. Hmyawyit. 4. Mawtin Point. 5. Zea Gyaing. 6. Ngwe Saung (Minn Lann). 7. Pho Htaung Gyaing. 8. Shwe Ya Gyaing. 9. Mazin (Ngapali). 10. Kyauk Phyu. Symbols: Distribution Distribution range of , Palisada parvipapillata; Distribution of , P. intermedia; Distribution range of , P. perforata; Taninthayi Taninthayi Coastal Zone; Taninthayi Deltaic Coastal Zone;Taninthayi Rakhine Coastal Zone.

Potential Uses: P. perforata (Bory) K.W. Nam as Laurencia papillosa is used as human food, drugs ${ }^{19-21}$ and in agriculture. ${ }^{22} L$. papillosa yielded lambda-carrageenan. ${ }^{23}$ It contains protein, fat and carbohydrate. ${ }^{24}$

\section{Discussion}

Comparison of the diagnostic characteristics, based on the external appearance and some anatomical features, in the species of the genus Palisada occur in Myanmar Coastal Zones, is shown in Table 1. The habit of the frond of vegetative plants is prostrate or decumbent and erect in Palisada parvipapillata (CK Tseng) K.W. Nam and $P$. perforata (Bory) $\mathrm{KW}$ Nam, whereas frond erect was observed in $P$. intermedia (Yamada) K.W. Nam. P. perforata (Bory) K.W. Nam grow on rocks and attached to substrate by discoidal holdfast along with stolon-like branches while $P$. parvipapillata (CK Tseng) KW Nam and $P$. intermedia (Yamada) K.W. Nam, which grow on rocks and attached to substrate by only discoidal holdfast without stoloniferous branches.

Fronds are terete in $P$. perforata (Bory) $\mathrm{KW}$ Nam, and $P$. intermedia (Yamada) KW Nam, whereas fronds are compressed in P. parvipapillata (C.K. Tseng) $\mathrm{KW} \mathrm{Nam}$. The width of main axis is narrow in $P$. perforata (Bory) KW Nam and P. intermedia (Yamada)
KW Nam with 0.8-1.2 $\mathrm{mm}$ in diameter, but wide in P. parvipapillata (CK Tseng) KW Nam with $0.8-2.5 \mathrm{~mm}$ in broad were observed in this study. Branching type is dichotomous or repeatedly pinnate in $P$. parvipapillata (CK Tseng) KW Nam, but whorled or spirally arranged in P. perforata (Bory) KW Nam and opposite or subverticillate in $P$. intermedia (Yamada) KW Nam (Table 1).

P. perforata (Bory) KW Nam has many papillate branchlets and lacks a palisade-like arrangement of cortical cells in transverse section. In contrast, $P$. intermedia (Yamada) KW Nam shows a palisade-like arrangement of the cortical cells. Palisade-like cortical cells are present in P. parvipapillata (CK Tseng) KW Nam and P. intermedia (Yamada) KW Nam. Secondary longitudinal pit-connection between cortical cells is present in P. parvipapillata (C.K. Tseng) KW Nam, and $P$. perforata (Bory) KW Nam. Projecting superficial cortical cells are present in $P$. parvipapillata (CK Tseng) KW Nam. The cortical cells of main axis in longitudinal section are slightly or radially elongated in $P$. perforata (Bory) KW Nam, and arranged like palisade layer in $P$. parvipapillata (CK Tseng) $\mathrm{KW}$ Nam and $P$. intermedia (Yamada) KW Nam (Table 1).

The shape of tetrasporangial branchlets is found to be cylindrical to clavate in $P$. intermedia (Yamada) KW Nam. The length of tetrasporangial branchlets are less than $700 \mu \mathrm{m}$ in P. intermedia (Yamada) KW Nam. Clustered tetrasporangial branchlets are encountered in $P$. intermedia (Yamada) KW Nam. The sexuality of P. perforata (Bory) KW Nam is dioecious in the present study. The ovoid-shaped cystocarps of $P$. perforata (Bory) KW Nam are borne laterally on the branches. The cystocarpic plants of P. parvipapillata (CK Tseng) K.W. Nam and P. intermedia (Yamada) K.W. Nam are unknown in the present study. The spermatangial stichidia of $P$. parvipapillata (CK Tseng) KW Nam and P. perforata (Bory) KW Nam are formed on the apical portions of main axis with apical cupshaped spermatangial pits. The spermatangial plants are unknown in P. intermedia (Yamada) KW Nam (Table 1).

The distributional range of the genus Palisada in Myanmar is from the southern limit of Zar Det Gyi I. (Lat. $09^{\circ} 56^{\prime} \mathrm{N}$, Long. $98^{\circ} 11^{\prime} \mathrm{E}$ ) of the Taninthayi Coastal Zone to the northern limit of Kyauk Phyu (Lat. $19^{\circ} 26^{\prime} \mathrm{N}$, Long. $93^{\circ} 33^{\prime} \mathrm{E}$ ) of the Rakhine Coastal Zone. $P$. parvipapillata (CK Tseng) KW Nam distributes from the southern limit of Kampani (Lat. $14^{\circ} 02^{\prime} \mathrm{N}$, Long. $98^{\circ} 04^{\prime} \mathrm{E}$ ) to the northern limit of Ngwe Saung (Minn Lann)(Lat. $16^{\circ} 52^{\prime}$ N, Long. 94 $22^{\prime}$ E) and $P$. perforata (Bory) $\mathrm{KW}$ Nam predominates from the southern limit of Zar Det Gyi I. (Lat. $09^{\circ} 56^{\prime} \mathrm{N}$, Long. $98^{\circ} 11^{\prime} \mathrm{E}$ ) to the northern limit of Kyauk Phyu (Lat. $19^{\circ} 26^{\prime} \mathrm{N}$, Long. $93^{\circ} 33^{\prime} \mathrm{E}$ ). However, $P$. intermedia (Yamada) KW Nam occurs only in Shwe Ya Gyaing (Lat. $17^{\circ} 34^{\prime} \mathrm{N}$, Long. $94^{\circ} 34^{\prime}$ E)(Figure 52)(Table 2). Generally, $P$. intermedia (Yamada) KW Nam occur only in the Rakhine Coastal Zone, and P. parvipapillata (CK Tseng) KW Nam and P. perforata (Bory) KW Nam distribute along both the Rakhine and Taninthayi Coastal Zones. There are no records of specimens collected from the Deltaic Coastal Zone.

The world-wide distributional range of the three species of the genus Palisada normally occur in Myanmar is from New Zealand as southernmost recorded limit in the Pacific Ocean to Netherlands as northernmost recorded limit in the Atlantic Ocean. In general, the three species, viz., $P$. parvipapillata (CK Tseng) KW Nam, $P$. perforata (Bory) KW Nam and $P$ intermedia (Yamada) KW Nam distribute throughout the tropical to temperate coastal areas. With 
regard to horizontal phytogeographical distribution, the plants of $P$. intermedia and $P$. perforata commonly occur especially from tropical to temperate coastal areas in all oceans, while $P$. parvipapillata remarkably predominates along the Indian Ocean and Pacific Ocean (Figure 53). Moreover, the vertical phytogeographical distribution ranges of $P$. perforata (Bory) $\mathrm{KW}$ Nam and $P$. parvipapillata (CK
Tseng) KW Nam are wide, from New Zealand as southernmost limit in the Pacific Ocean to Netherlands in the Atlantic Ocean and Japan in the Pacific Ocean as of northernmost limit, whereas that of $P$. intermedia (Yamada) KW Nam are remarkably narrow, from Reunion of Indian Ocean as southernmost limit to Turkey of the Atlantic Ocean as of northernmost limit.

Table I Comparison of the taxonomic features in Palisada spp. from Myanmar

Species

\begin{tabular}{|c|c|c|}
\hline Sr. No. & Characters & $\begin{array}{l}\text { Palisada parvipapillata (CK } \\
\text { Tseng) KW Nam }\end{array}$ \\
\hline & \multicolumn{2}{|l|}{ Vegetative Structures } \\
\hline 1 & $\begin{array}{l}\text { Habit of plants with type } \\
\text { of holdfast }\end{array}$ & $\begin{array}{l}\text { Decumbent or prostrate, } \\
\text { attached by means of discoid } \\
\text { holdfast }\end{array}$ \\
\hline 2 & $\begin{array}{l}\text { Height or diameter of } \\
\text { plants }\end{array}$ & $2-3 \mathrm{~cm}$ \\
\hline 3 & $\begin{array}{l}\text { Shape of main axis in } \\
\text { cross-section }\end{array}$ & Compressed \\
\hline 4 & Size of main axis & $0.8-2 \mathrm{~mm}$ in broad \\
\hline 5 & Branching type & $\begin{array}{l}\text { Pinnately or alternately } \\
\text { branched }\end{array}$ \\
\hline 6 & Palisade-like cortical cells & Present \\
\hline 7 & $\begin{array}{l}\text { Secondary longitudinal } \\
\text { pit-connection between } \\
\text { cortical cells }\end{array}$ & Present \\
\hline 8 & $\begin{array}{l}\text { Projecting superficial } \\
\text { cortical cells }\end{array}$ & Present \\
\hline 9 & $\begin{array}{l}\text { Shape and size of cortical } \\
\text { cells in surface view }\end{array}$ & $\begin{array}{l}\text { Elongated, palisade-like cells } \\
\text { and } 20-48 \mu \mathrm{m} \text { long, } 12-20 \mu \mathrm{m} \text { in } \\
\text { broad }\end{array}$ \\
\hline 10 & $\begin{array}{l}\text { Shape and size of } \\
\text { medullary cells in cross } \\
\text { section }\end{array}$ & $\begin{array}{l}\text { More or less rounded or } \\
\text { elongated and } 44-\mid 40 \mu \mathrm{m} \text { long, } \\
28-88 \mu \mathrm{m} \text { in broad }\end{array}$ \\
\hline II & $\begin{array}{l}\text { Formation style } \\
\text { and arrangement } \\
\text { tetrasporangia }\end{array}$ & - \\
\hline \multirow[t]{2}{*}{12} & $\begin{array}{l}\text { Type and size of } \\
\text { tetrasporangia }\end{array}$ & - \\
\hline & Reproductive structures & \\
\hline 13 & $\begin{array}{l}\text { Shape and size of } \\
\text { tetrasporangial brabches }\end{array}$ & - \\
\hline 14 & $\begin{array}{l}\text { Shape and size of } \\
\text { spermatangial pit }\end{array}$ & $\begin{array}{l}\text { Cup-shaped and } 1025-1525 \mu \mathrm{m} \\
\text { long, and II } 25-1850 \mu \mathrm{m} \text { broad }\end{array}$ \\
\hline 15 & $\begin{array}{l}\text { Shape and size of } \\
\text { cystocarp }\end{array}$ & - \\
\hline
\end{tabular}

\section{Palisada intermedia} (Yamada) KW Nam

Erect, attached by means of discoid holdfast with stolon-like branches

Up to $5 \mathrm{~cm}$

Terete

$0.6-1.2 \mathrm{~mm}$ in diameter

Opposite or subverticillate

Present

Absent

Absent

Hexagonal and 8-18 $\mu \mathrm{m}$ long, $8-13 \mu \mathrm{m}$ in broad

Rounded or more or less elongated and 50-190 $\mu \mathrm{m}$ diameter

Simple or in clusters and perpendicular

Tetrahedrally divided and $90-100 \mu \mathrm{m}$ in diameter

Cylindrical to clavate and

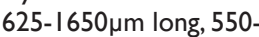
$900 \mu \mathrm{m}$ in broad

\section{Palisada perforata (Bory)} KW Nam
Erect or prostrate, attached by means of discoid holdfast with stolon-like branches

$1.0-3.5 \mathrm{~cm}$

Terete

0.8-I.0mm diam.

Distichous to tristichous

Absent

Present

Absent

More or less rounded or rectangular and $12-20 \mu \mathrm{m}$ long, 12-16 $\mu \mathrm{m}$ wide

More or less rounded and 52 $100 \mu \mathrm{m}$ in broad

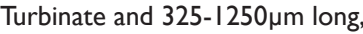
$625-1625 \mu \mathrm{m}$ in broad

Ovoid and 625-1375 $\mu \mathrm{m}$ long, $550-875 \mu \mathrm{m}$ in broad 
Table 2 The distributional range of the genus Palisada Nam along the three Coastal Regions in Myanmar

\begin{tabular}{|c|c|c|c|c|c|c|c|}
\hline & \multirow{3}{*}{ Species } & \multicolumn{6}{|c|}{ Coastal Regions } \\
\hline & & TCZ & & DCZ & & $\mathbf{R C Z}$ & \\
\hline & & From & To & From & To & From & To \\
\hline
\end{tabular}

\begin{tabular}{|c|c|c|c|c|c|c|}
\hline & & Kampani & Hmyaw-yit & & & Ngwe Saung (Minr \\
\hline & $\begin{array}{l}\text { Palisada parvipapi-llata (CK } \\
\text { Tseng) KW Nam }\end{array}$ & $\begin{array}{l}\text { (Lat. } \\
14^{\circ} 02^{\prime} \mathrm{N} \text {, Long. } \\
\left.98^{\circ} 04^{\prime} \mathrm{E}\right)\end{array}$ & $\begin{array}{l}\text { (Lat. } \\
\text { I } 4^{\circ} 04^{\prime} \mathrm{N} \text {, } \\
\text { Long. } \\
\left.98^{\circ} 04^{\prime} \mathrm{E}\right)\end{array}$ & No data & $\begin{array}{l}\text { No } \\
\text { data }\end{array}$ & $\begin{array}{l}\text { (Lat. } \\
16^{\circ} 52^{\prime} \mathrm{N} \text {, } \\
\text { Long. } \\
\left.94^{\circ} 22^{\prime} \mathrm{E}\right)\end{array}$ \\
\hline
\end{tabular}

\begin{tabular}{|c|c|c|c|c|c|c|c|}
\hline 2. & $\begin{array}{l}\text { P. interme-dia (Yamada) KW } \\
\text { Nam }\end{array}$ & No data & No data & No data & $\begin{array}{l}\text { No } \\
\text { data }\end{array}$ & $\begin{array}{l}\text { Shwe Ya Gyaing } \\
\text { (Lat. 17 } 34^{\prime} \mathrm{N} \text {, Long. } \\
\left.94^{\circ} 34^{\prime} \mathrm{E}\right)\end{array}$ & - \\
\hline 3. & P. perforata (Bory) KW Nam & $\begin{array}{l}\text { Zar Det Gyi } \\
\text { (Lat. } \\
09^{\circ} 56^{\prime} \mathrm{N}, \\
\text { Long. } \\
98^{\circ} \text { I I'E) }\end{array}$ & No Data & $\begin{array}{l}\text { No } \\
\text { Data }\end{array}$ & $\begin{array}{l}\text { No } \\
\text { Data }\end{array}$ & $\begin{array}{l}\text { Mawtin Point } \\
\text { (Lat. } \\
15^{\circ} 58^{\prime} \mathrm{N} \text {, } \\
\text { Long. } \\
\left.94^{\circ} \text { I } 4^{\prime} \mathrm{E}\right)\end{array}$ & $\begin{array}{l}\text { Kyauk Phyu } \\
\text { (Lat. } \\
19^{\circ} 26^{\prime} \mathrm{N} \text {, Long. } \\
93^{\circ} 33^{\prime} \mathrm{E} \text { ) }\end{array}$ \\
\hline
\end{tabular}

The distributional range of the genus Palisada Nam along the three Coastal Regions in Myanmar.

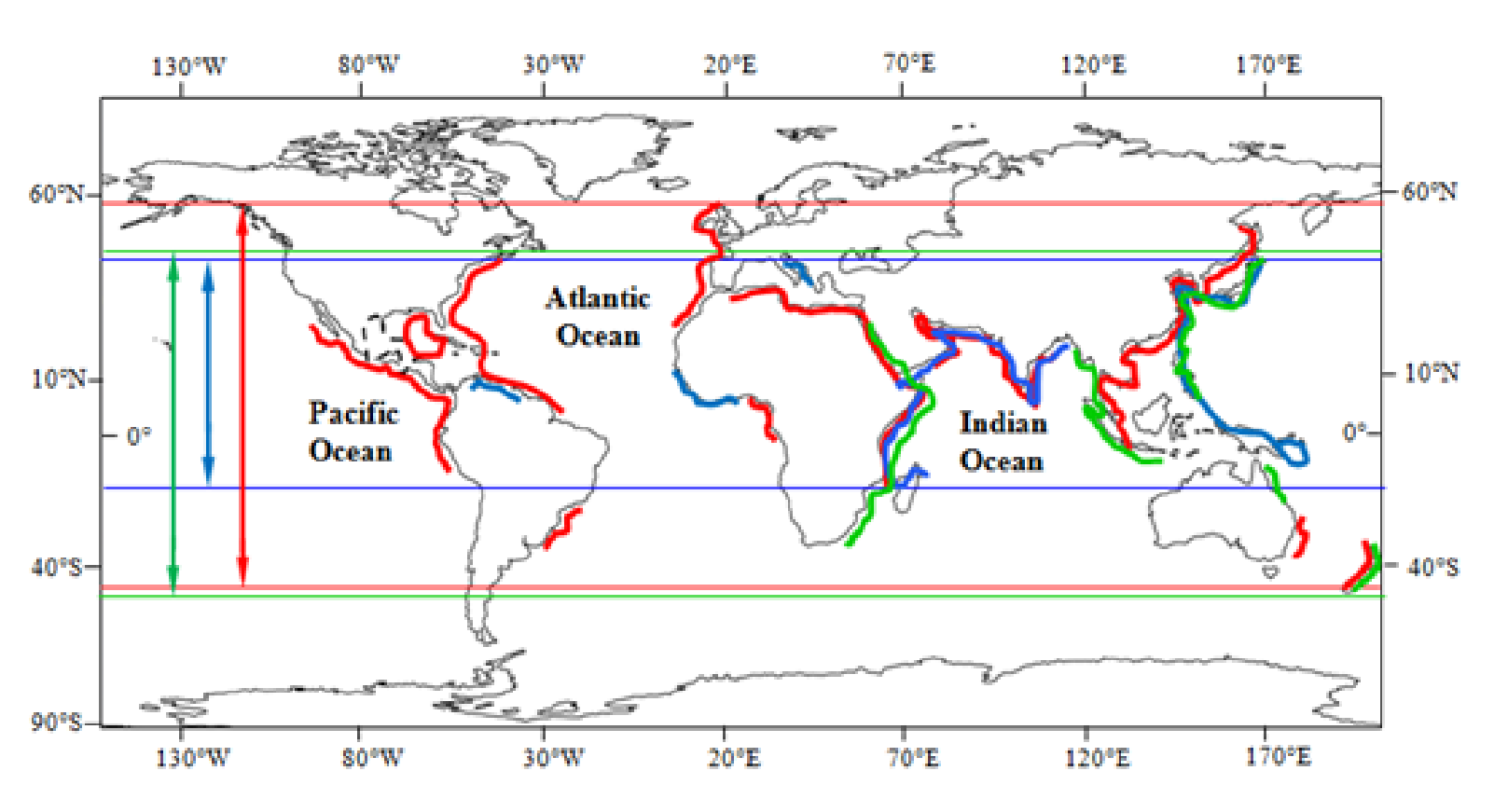

Figure 53 Phytogeographical distribution of the genus Palisada Nam. Symbols: Potential distribution range and southernmost and northernmost recorded limits of Palisada parvipapillata; Potential distribution range and southernmost and northernmost recorded limits of $P$. intermedia, and Potential distribution range and southernmost and northernmost recorded limits of P. perforata. 
In general, the result of the study on the phytogeographical distribution of the three species of the genus Palisada, namely $P$. parvipapillata (C.K. Tseng) KW Nam, P. perforata (Bory) KW Nam and $P$. intermedia (Yamada) KW Nam clearly supports a potential distribution of these three species in Myanmar, being one of the countries in the Indian Ocean Region (IOR).

\section{Conclusion}

The present study confirmed the occurrence of three species of Palisada, namely Palisada parvipapillata (CK Tseng) KW Nam, $P$. intermedia (Yamada) KW Nam and P. perforata (Bory) KW Nam, in Taninthayi and Rakhine Coastal Zones of Myanmar. All these 3 species are newly recorded from Myanmar waters. This study reveals that fronds are terete in $P$. perforata (Bory) $\mathrm{KW}$ Nam, and $P$ intermedia (Yamada) KW Nam, whereas fronds are compressed in $P$. parvipapillata (CK Tseng) KW Nam. The width of main axis is narrow in $P$. perforata (Bory) $\mathrm{KW}$ Nam and $P$. intermedia (Yamada) KW Nam, but wide in P. parvipapillata (CK Tseng) KW Nam. Branching is dichotomous or repeatedly pinnate in P. parvipapillata (CK Tseng) KW. Nam, but whorled or spirally arranged in P. perforata (Bory) KW. Nam and opposite or subverticillate in P. intermedia (Yamada) KW Nam. In the present study, the only specimen collected from Shwe Ya Gyaing was used for identification of P. intermedia (Yamada) KW Nam. Further studies on the spermatangial and carpogonial plants of P. intermedia (Yamada) KW Nam are necessary to be done. Moreover, studies on tetrasporangial and cystocarpic plants of $P$. parvipapillata $\mathrm{CK}$. Tseng (KW Nam) and tetrasporangial plants of $P$. perforata (Bory) KW Nam are also needed to add some new outcomes for confirmation of the species concerned. The following characteristics are generally used to identify each species of Palisada from Myanmar.

\section{Key to the species of Palisada from Myanmar}

1. Fronds distinctly compressed and prostrate or decumbent, branching pinnately or alternately.........Palisada parvipapillata

2. Fronds terete and erect or prostrate, branching not as above...........2

2a. Branching opposite or subverticillate.........P. intermedia

2b. Branching di-tristichous, whorl or alternately dichotomous or irregularly spirally arranged.......P. perforate.

This study shows $P$. parvipapillata $\mathrm{CK}$ Tseng (KW Nam) and $P$. perforata (Bory) KW Nam commonly predominate along both the Taninthayi and Rakhine Coastal Zones whereas $P$. intermedia (Yamada) KW Nam uniquely occur in the Rakhine Coastal Zone. Further studies on the distribution of the genus Palisida along the 3 Coastal Zones of Myanmar are still needed. With regard to the worldwide distribution of the plants of Palisida, P. intermedia (Yamada) KW Nam and $P$. perforata (Bory) KW. Nam commonly distribute in all tropical and temperate oceans while $P$. parvipapillata $\mathrm{CK}$ Tseng (KW Nam) remarkably occurs predominantly in the Indian and Pacific Oceans. The local distribution of the species of Palisada from Myanmar is closely related to that of the world-wide distribution of the species of Palisada from the Indian and Pacific Oceans.

\section{Acknowledgements}

We are indebted to Dr. Aung Myat Kyaw Sein, Acting-Rector, and Dr. Mie Mie Sein and Dr. San San Aye, Pro-Rectors, Mawlamyine University, for their supports and encouragement in this study. We are grateful to Dr. San Tha Tun, Professor, Head of Department of Marine Science, Mawlamyine University, for his generous supports and useful suggestions, during this research works done in the Phycological Research Laboratory. We are thankful to the late Dr. Min Thein, Director (Retd.) Microalga Biotechnology Department, Myanmar Pharmaceutical Factory (MPF), Yangon, Myanmar for his academic guidance and literature provided. Our special thanks go to Dr. Mya Kyawt Wai, Dr Jar San and Dr. Sein Moh Moh Khaing, Department of Marine Science, Mawlamyine University for their valuable assistance throughout the course of this study. We would like to thank U Zaw Lin Tun, Staff of Marine Science Association, Myanmar (MSAM) for his helpful assistance in the preparation of the manuscript.

\section{Conflict of interests}

Author declares that there is no conflict of interest.

\section{References}

1. Saito Y. Studies on Japanese species of Laurencia, with special reference to their comparative morphology. Mem FacFish, Hokkaido Univ. 1967. $81 \mathrm{p}$.

2. Nam KW, Maggs CA, Garbary DJ. Resurrection of the genus Osmundea with an emendation of the generic delineation of Laurencia (Ceramiales, Rhodophyta). Phycologia. 1994;33(5):384-395.

3. Nam KW. Validation of the generic name Palisada (Rhodomelaceae, Rhodophyta). Korean Journal of Phycology. 2007;22: 53-55.

4. Serio D, Cormaci M, Furnari G, et al. First record of Palisada marisrubri (Ceramiales, Rhodophyta) from the Mediterranean Sea along with three proposed transfers to the genus Palisada. Phycological Research. 2010;58:9-16.

5. Guiry MD, Guiry GM. Algae Base. World-wide electronic publication, National University of Ireland, Galway. 2018

6. Kyi Win. A classified list of the seaweeds of Myanmar. Proceedings of the Myanmar Research Congress. 1972;25-29.

7. Kyaw Soe, Kyi Win. Seaweeds for utilization. University Translation and Publication Department. Myanmar. 1977;2(168): 502.

8. Soe-Htun U, Mu Mu Aye, Soe Pa Pa Kyaw. Distribution and potential uses of marine algae found along the three Coastal Regions of Myanmar. Department of Marine Science. Mawlamyine University. Tech. Rep. 2007; $190 \mathrm{p}$.

9. Soe-Htun U, Mya Kyawt Wai, Thida Nyunt. Notes on some marine benthic red algae of Gwa Coastal Areas I: Rhodophyta (Goniotrichales, Stylonematales, Erythropeltidales, Bangiales, Acrochaetiales, Nemaliales, Corallinales, Gelidiales and Halymeniales). Jour. Myan. Acad. Arts \& Sc. 2009;7(5):215-142.

10. Zayar Aung. Study on the marine benthic red algae of Kampani coastal areas. Unpublished Master of Science Thesis. Department of Marine Science. Mawlamyine University. 2012.

11. Myo Min Tun. The floras and ecology of macrobenthic marine algae in Kampani coastal areas. Unpublished Master of Research Thesis. Department of Marine Science. Mawlamyine University. 2013.

12. Soe Pa PaKyaw. Systematics of Laurencia complex (Ceramiales, Rhodophyta) of Myanmar. Unpublished PhD Dissertation. Department of Marine Science. Mawlamyine University. 2014.

13. Saito Y. The algal genus Laurencia from the Hawaiian Islands, the Philippine Islands and adjacent areas. Pacific Science. 1969;23(2):148160. 
14. Cordero PA. Studies on Philippine marine red algae. Special. Publ. Seto Marine Biol. Lab., Series IV. Contr Seto Mar. Biol.1977;4:1-258.

15. Silva PC, Menez EG, Moe RL. Catalogue of the benthic marine algae of the Philippines. Smithsonian Contributions to Marine Science. 1987;27:1-179.

16. Silva PC, Basson PW, Moe RL. Catalogue of the benthic marine algae of the Indian Ocean. Univ Calif Publ Bot. 1996; 9:1259.

17. Chapman VJ. Seaweeds in pharmaceuticals and medicine: A review. In: Hoppe HA, Levring T, Tanaka Y, editors. Marine algae in pharmaceutical science. Walter de Gruyter.1979; p. 139-147.

18. Dembitsky VM, Tolstikov GA. Natural halogenated sesquiterpenes from marine organisms. Chemistry for Sustainable Development. 2004;12:112.

19. Levring T, Hoppe HA, Schmid OJ. Marine algae: A survey of research and utilization. Botanica Marina. 1969;1:1-421.
20. Trono GC Jr. 1977. Guide to Philippine flora and fauna. Seaweeds Vol. I. Economically important seaweed. Department of Natural Resources. 1977; 75 p.

21. Soe Htun U, Hla Tint, San Tha Tun. A review on the seaweed research in Myanmar. Department of Marine Science. Mawlamyine University. Technical Report. 1997; 27p.

22. Zemke White WL, Ohno M. World seaweed utilization: An end-ofcentury summary. Journal of Applied Phycology. 1999; 11(4):369-376.

23. Zablackis EK, Mc Dermid KJ. Agar from a species of Laurencia, a red seaweed from the Hawaiian Islands. In: Abbott IA editors, Taxonomy of economic seaweeds with reference to some Pacific and Caribbean species. California Sea Grant College Program, University of California. $1988 ; 2: 253-256$

24. Khalil AN, El-Tawil BAH. Phytochemical studies on marine algae from Jeddah, Red Sea. Bull Fac Sci, Jeddah. 1982;6:49-60. 